\section{Public libraries in Turkey: A retrospective look and the present state}

\author{
Umut Al and Sinan Akıllı \\ Hacettepe University, Turkey
}

Journal of Librarianship and Information Science

(C) The Author

(C) The Author(s) 2015
Reprints and permissions:

sagepub.co.uk/journalsPermissions.nav DOI: I0.1 I77/09610006I5592456 lis.sagepub.com

\begin{abstract}
The present study offers an overview of the public library system in Turkey and evaluates the libraries from various aspects in the context of the past decade. Public libraries in Turkey are governed by the Ministry of Culture and Tourism. As of the end of 20I3, there are 1 I 18 public libraries in Turkey with more than one million registered users which is only I.3\% of the total population of the country. The total number of staff in the 1 I 18 public libraries is approximately 3400 , of which only $15 \%$ are graduates of librarianship programs. As regards collection size, it is observed that there has been a consistent increase in the number of books in public library collections. When considered together with the rate of increase in the total number of registered public library users, however, there has been a major decrease in the number of books per registered public library user in the past decade. The budget allocated for public libraries in Turkey has been consistently greater each year. The public libraries in Turkey offer their services in buildings that vary significantly in terms of architectural design. In general, public libraries in Turkey have been on a developing trend in recent years. On the other hand, the comparisons made in this study with other European countries suggest that there are a number of issues related to public libraries in Turkey that need to be improved.
\end{abstract}

\title{
Keywords
}

Public libraries, public libraries in Turkey, Turkey

\section{Introduction}

Public libraries are institutions that serve everyone regardless of their language, religion, race, age and gender and, in so doing, they contribute to the availability of information in society. In this context, it is an undeniable fact that public libraries play a crucial role in the process of the socialization of information. As has been the case for many other institutions, the emergence of modern public libraries has not occurred in a short period of time. It has been argued that public libraries have been shaped into what they are today over a period of more than 200 years (Shera, 1949). Constantly evolving in time, public libraries are compelled to keep up with not only international developments, but also, due to their nature, the local dynamics of the communities they serve.

The growing importance given to public libraries is undoubtedly due to the expansion of the volume of information and to the visible increase in the number of people who demand information. With the availability of information access technologies as a function of the modern public library, the library use rate of individuals who cannot access these technological tools through their own means has also increased. Therefore, public libraries have been rapidly advancing towards becoming "community centers."
In this study, an overview of the current state of public libraries in Turkey ${ }^{1}$ is given, and the public libraries are studied with reference to the five main elements that constitute public library information centers, namely staff, users, collections, budget and buildings. Furthermore, public library related statistical data from various other European countries are compared with similar data from Turkey.

\section{History of public libraries in Turkey}

Before attempting a detailed account of the history of public libraries in Turkey, one must note that at the time of the founding of the Republic of Turkey there had already been a long tradition of libraries in the land. However, since the library institution in the pre-Republic periods, such as the Seljukian and the Ottoman, was only accessible by a privileged elite and not by the "public," any account of the Turkish public library system in the

\footnotetext{
Corresponding author:

Umut Al, Department of Information Management, Hacettepe

University, Ankara, Turkey.

Email: umutal@hacettepe.edu.tr
} 
modern sense of the term, must take the foundation of the Republic as the starting point.

With the foundation of the Republic, the task of overseeing all existing libraries was given to Maarif Vekaleti Hars Dairesi (Ministry of Education, Department of Culture). The 1925 report prepared by Dr Hamit Zübeyir Koşay, who was the director of this institution, is a very valuable document for an understanding of the history of Turkish libraries, including public libraries. Accounting for the situation in 1925, the report states that of the 64 provinces of the Republic of Turkey, 45 did not have a public library; and similarly, of the 395 districts, 366 did not have a library open to the public. The report also reveals that while libraries in İstanbul had hundreds of thousands of books, there were only 70,000 volumes in the whole of Anatolia, which were nowhere near to meeting the demands of the contemporary reading public. With reference to its findings, the report underlines the compelling need to reform the libraries so they could meet the requirements of their times (Koşay, 1960).

It has been observed that from 1932 to 1950 , the libraries located in People's Houses ${ }^{2}$ mostly adopted the function of public libraries in Turkey. In 1945, there were 82 public libraries and 395 People's House libraries in Turkey. Moreover, there were 230 public reading rooms and 366 public rooms which served a similar purpose. By 1948, the total number of People's House libraries, community reading rooms, and community rooms had reached 4730 (Baysal, 1992: 58-59). Even though not directly related to the transformation of the public library system in those decades, it is worth noting that another manifestation of the general interest in the library institution in this period was the foundation of the National Library. The work for its foundation having already started in 1946, the National Library eventually welcomed its first users in 1948. With the Foundation Law dated 29 March 1950, the National Library also gained a legal institutional identity (Milli Kütüphane, 2014).

In addition to the findings of the report prepared by Koşay, it may be observed that following the foundation of the Republic, libraries have been affected, either directly or indirectly, by various developments. Among these developments, the most significant were the 1924 Law of the Unification of Curriculum (Tevhid-i Tedrisat Капипи), which ensured a standard national curriculum to minimize the inequalities in the national education system; the Script Reform of 1928 (Harf Devrimi), which radically impacted the spread of literacy among the public due to the relative ease of learning the Latin alphabet; and the Libraries Committee Report (Kütüphaneler Komitesi Raporu). In particular, the Libraries Committee Report that was published in 1961 introduced the concept of 'planning' of libraries and the Committee's work was aimed at planning the next 10 years of the libraries (Y1lmaz, 2004).
The foundation of the Ministry of Culture in the early 1970s was a major milestone in the development of public libraries in Turkey. Even though public libraries were not affiliated with the Ministry of Culture in the first years of its foundation, in time the Ministry of Culture ${ }^{3}$ evolved into being the highest authority in the organizational structure of public libraries in Turkey.

In the 1980s and 1990s there was a concentration of efforts toward developing the legislation that was related to public libraries. These efforts, including a number of guides, regulations and bills, may be considered as important steps toward the increase in awareness of public libraries and the deliberate purpose of improving their services. Today, public libraries in Turkey operate in compliance with the Public Libraries Regulations published in 2012. However, as of 2014, Turkey does not still have a Public Libraries Law. It is known that in many other countries, public library legislation was put into effect many years ago and positively impacted the services of public libraries (Gardner, 1971).

\section{The public library system in Turkey}

It is known that the organization of public library services varies across countries. In developing their public library systems with respect to their own circumstances, countries also take into account international trends. With a rough classification, it is possible to mention three different organizational systems for public libraries: local-level, state-level and centralized. The public library system that is based on local governments is a system typically seen in countries where there are strong local government structures, especially on the basis of provinces (e.g. United Kingdom). In countries where the state-level public library organization is seen (e.g. the USA), the central government holds most of the legislative and judicial powers, but public library services and their organization are decided at the state level. In only a few countries, including Turkey, is a centralized public library system observed. In this type of organization, public libraries are answerable to ministries of culture or education via some intermediary units. In this system, public libraries are also accountable to the central government in administrative and technical services. All related legislation and regulations are issued by the central government and they apply to all of the public libraries in the given country (Y1lmaz, 2005: 58-59). The public libraries of Turkey are organized under the body of the Ministry of Culture and Tourism and they are governed by the GDLP. This form of organization entails both advantages and disadvantages for public libraries.

The most significant advantage of the centralized structure in Turkey is the ability of the GDLP to develop national strategies to address the problems of public libraries. The existing centralized public administration structure in Turkey ensures - if the political authority in power 
is in favor of strong libraries - that public libraries benefit from the allocation of government resources (staff, funds, etc.) On the other hand, the very same structure may easily turn into a disadvantage for public libraries, if the central government's attitude toward libraries is not as positive.

As has been mentioned above, the prevalent position of the central government in the administration of the national public library system in Turkey assigns legislative power to this centralized authority, and as an example of this, the Public Libraries Regulations which took effect in 2012 provide the standards for the operation of public libraries in Turkey. Detailing such issues as criteria to open a new public library in a given settlement area, the minimum qualifications of the library staff, and the ratio of the sources that address the needs of children in the entire collection owned by a given public library, the Regulations theoretically represent another advantage of having a centralized public library system. However, in practice, the applicability of these Regulations must be questioned in the absence of a Public Libraries Law that would have formed a much stronger legal basis to guarantee the observance of the Regulations. As legal documents, regulations in Turkey are issued by government institutions at various levels to specify the details of the implementation of laws, which are legislative documents issued by the Parliament and therefore, of a higher status. Currently, the Public Library Regulations in Turkey are part of the Law for the Foundation of Ministry of Culture and Tourism No: 4848, which basically specifies the organizational structure and the duties of the Ministry. That is to say, without a Public Libraries Law that would primarily focus on the public library system, the Regulations are weak in terms of the enforcement of their rules and principles. For instance, in the current state of affairs, a given public library may easily be closed or its facilities be transferred to another public institution and used for purposes other than those of a public library. Based on the examples from other countries, such as the United Kingdom where a Public Libraries Act has existed since 1850 (Williamson, 2000), it may be argued that a Public Libraries Law would further empower the public library system in Turkey. Presently, the prospect of a Public Libraries Law in Turkey seems distant, as the central government is considering devolving the duty of administering public libraries to local government.

The transfer of the public libraries in Turkey to local government has long been debated by various stakeholders. Those who oppose the transfer to local government make their case by claiming that local councils will not pay much attention to public libraries, especially with reference to the primary duties of local government as defined by existing legislation which does not enforce any such duties. Another objection to the taking over of the administration of public libraries by local government is based on the rationale that local councils tend to be very different from one another (in terms of both resources and attitudes), which is likely to cause an inequality in the provision of services by the libraries to the public, and that will, in turn, result in the underserving of some potential library users.

As the debate on the transfer of public libraries to local government continues, some public libraries are being closed down due to insufficient funds, staff and physical infrastructure. Even though the public libraries in Turkey have been defined as public institutions that help the diffusion of reading habits in society and ensure the equal distribution of information products among citizens, the number of actively serving public libraries today differs widely from one province to the other (see Figure 1). Although small in number, there is also a group of public libraries that are temporarily closed due to building renovation works.

\section{Research on public libraries in Turkey}

Several studies on public libraries in Turkey have been published in both national and international literature (Keseroğlu，1989; Sağlamtunç, 1995; Yalvac，2004; Yllmaz, 1998, 2008, 2010). In these studies, findings about the role of the public libraries in Turkey have been presented in the form of various statistical data. Moreover, these studies also scrutinize the structure that governs the libraries, as well as the insufficiencies of public libraries. In one of these studies (Y1lmaz, 2008: 217), for instance, the failure to achieve the desired level of ICT use in public libraries has been dealt with under three main headings: lack of strategy, lack of funds, and lack of staff. Another study (Sağlamtunç, 1995) has focused on the distribution of public libraries across different geographical regions in Turkey to point out the imbalance in this distribution. While $28 \%$ of all public libraries are located in the Central Anatolian Region, the figure for Eastern Anatolia is below 5\%, for example (Sağlamtunç, 1995: 245). Although several studies offer statistical evaluations of different periods, there does not seem to be any particular study which deals with the present situation. In a previous study (Yalvac, 2004), the 1996-2002 period was investigated and yet another study (Y1lmaz, 2010) evaluated a longer period (1990-2008). These previous studies are useful particularly for those who are interested in gaining a broad overview of the state of the public libraries in Turkey.

It is also known that a significant amount of graduate research has been carried out in the librarianship schools in Turkey. Most of these studies are Masters theses and the number of doctoral dissertations on the subject is quite low. Nonetheless, with reference to the density of these studies, it would not be wrong to argue that there has been a visible increase of interest in the subject.

Discussions of the problems of public libraries in Turkey have so far been the theme of three Public Librarianship Symposia. The first of these meetings was held in 1993, followed by the second one about 20 years later. The 3rd Public Librarianship Symposium was held in 


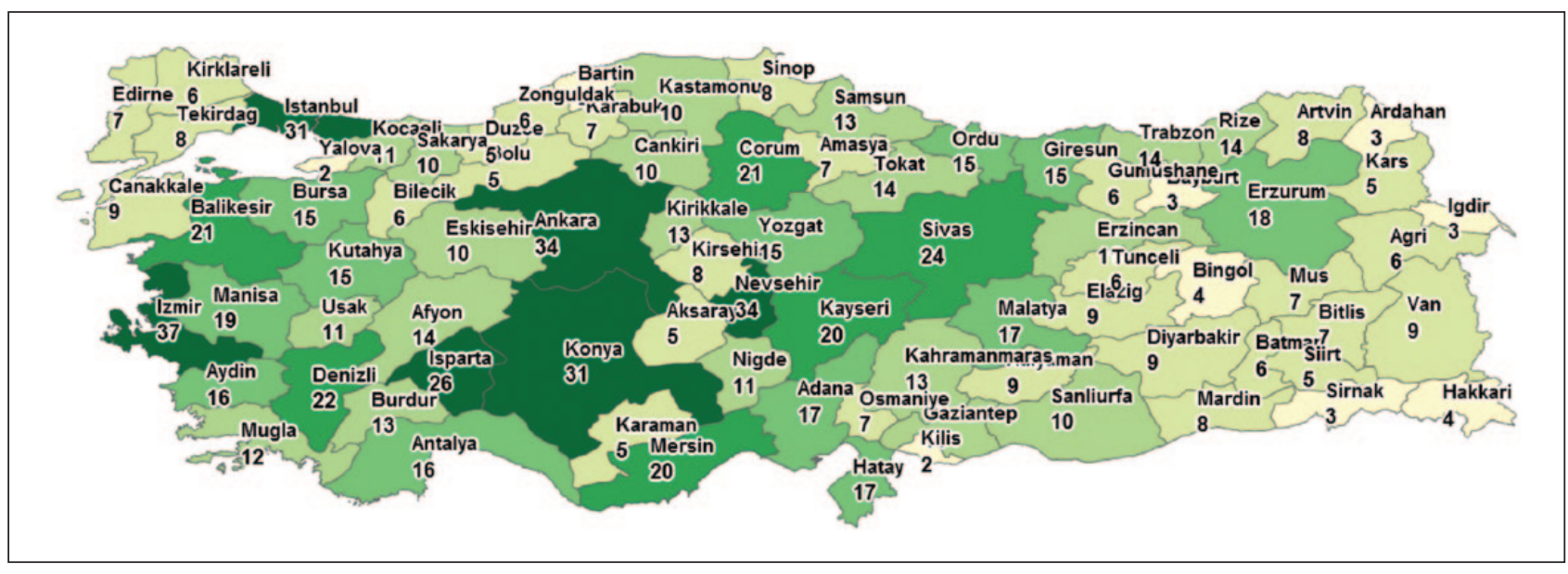

Figure I. Number of public libraries in the provinces of Turkey. Source: Kültür ve Turizm Bakanlığı (20l4).

2013. These meetings not only bring public librarians together on the same platform, but also provide opportunities for them to increase their level of knowledge.

In addition to academic studies, there have also been practice-oriented works. In this context, it is meaningful to mention some activities and projects carried out in Turkey in relation to public libraries. For example, the Ministry of Culture and Tourism launched the "Improvement of Children's and Public Libraries Project." With this project, first the provinces and districts with insufficient premises were identified and, in collaboration with local government, existing library premises were improved and modern library services offered. Within the frame of another project, namely the "Project for the Establishment of Public Internet Access Centers at Province Public Libraries," at 81 provincial public libraries, the Ministry-affiliated İstanbul Beyazıt State Library, and 18 district public libraries, all of the necessary hardware products (computers, printers, scanners, and copiers) were installed and ADSL Internet connections were provided. The Public Internet Access Centers are offered by these libraries free of charge. Another project supported by the GDLP is the "You are not Disabled in Accessing Information (BİLED)" Project. The project was launched in 85 provincial and district public libraries in order to facilitate visually-impaired people's access to information resources, to contribute to their self-development and enrich their leisure options, and to support their families and educational institutions (KYGM, 2013).

Another major effort was the "Benim Kütüphanem Projesi" (My Library Project) launched in 2006 in partnership with the Community Volunteers Foundation (Toplum Gönüllüleri Vakfi) and the Ministry of Culture and Tourism. The aim of the project was to reorganize provincial public libraries, to take the measures necessary for making the users aware of new services, and to help revitalize some relatively underused libraries by adapting the services to the needs of the local communities. Almost simultaneously with the project, regional seminars were organized in order to offer a continuous in-service training model for public librarians in Turkey to help them stay up to date with professional developments and new ideas and to increase their professional qualifications, which was very significant as a project for the public libraries. The seminars that were organized in 18 different provinces and one district through the collaboration of various institutions for a period of six years were attended by 782 participants and around 100 speakers (Y1lmaz, 2013a: 180-181).

The most recent project toward the improvement of public libraries is the "Kütüphan-e Türkiye Planlama ve Pilot Uygulama Projesi" (Librar-e Turkey Planning and Pilot Project) which is a collaborative effort by Hacettepe Technopolis-Technology Transfer Center, the Ministry of Culture and Tourism and the Bill \& Melinda Gates Foundation's Global Libraries Initiative, which is the main funding provider. Within the scope of the 28-month Planning and Pilot Project which officially started on 1 July 2013, the aim is to achieve improvement in terms of ICT infrastructure and the computer-Internet literacy of both the staff and the users of public libraries at 78 public libraries of varying sizes located in 26 provinces that statistically represent Turkey (Kütüphan-e Türkiye, 2014).

\section{The present state of public libraries in Turkey}

As of 2013, the public library system in Turkey consists of 1118 libraries, 81 of which are provincial public libraries; the rest operate as district public libraries, children's libraries, and literature-museum libraries. In this study, the present state of the public libraries in Turkey will be dealt 


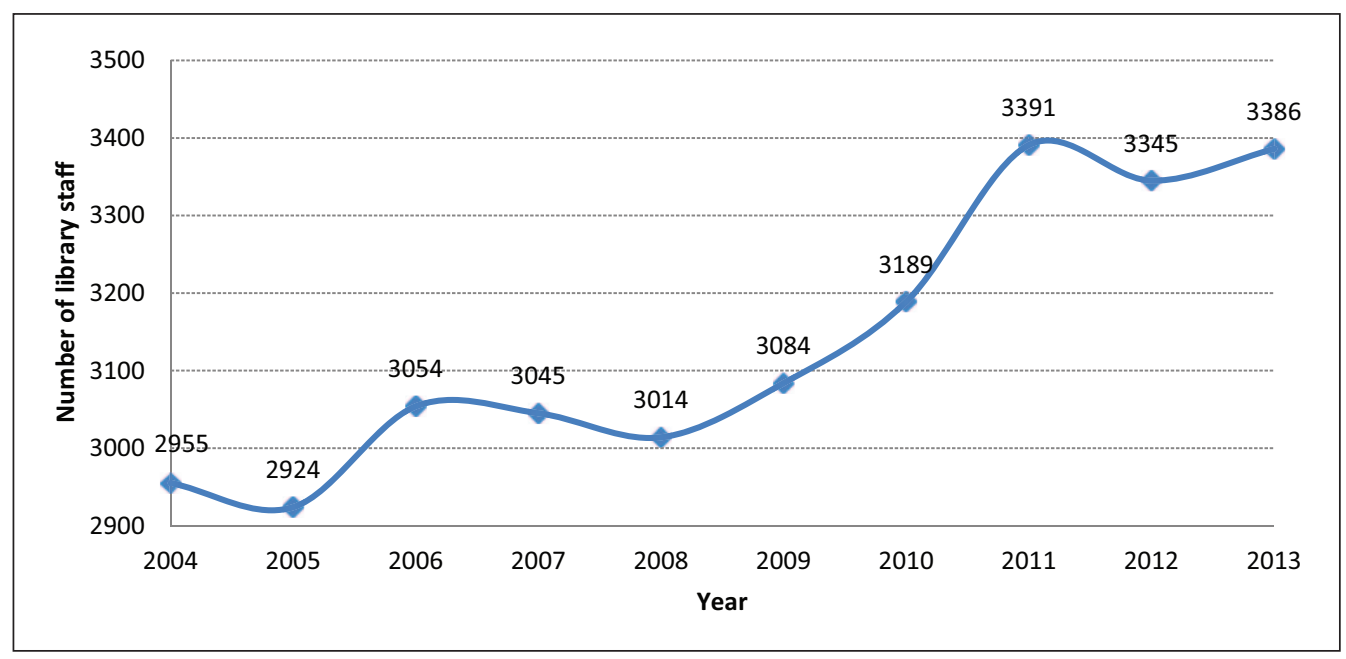

Figure 2. Total number of public library staff in the 2004-2013 decade. Source: Kültür ve Turizm Bakanlığı (20।4).

with under the subheadings of buildings, staff, users, collections, and budget.

\section{Buildings}

In general, public library buildings in Turkey are owned by public institutions. The Ministry of Culture and Tourism ranks as first in terms of the ownership of the buildings. It is also known that, even though small in number, some public libraries provide services in buildings owned by private individuals and village-level public entities. To make a general observation, it is understood that most of the buildings that are currently used by public libraries have not been designed for this specific purpose at the time of their construction. Therefore, the level of functionality of these buildings in terms of the delivery of information services must be questioned. In recent studies, the efficiency of public library buildings in terms of accessibility by the disabled, and their level of compliance with contemporary standards with reference to ergonomic elements have been investigated. It is known that especially in the recent years there have been efforts to improve access to public library buildings by the disabled through the construction of ramps and the installation of elevators. However, several public libraries are still not able to offer services under desired circumstances.

Another recent point of inquiry related to public libraries in Turkey has been the aesthetics of space, which has been scrutinized from various points of view (Hazırlar, 2004; Y1lmaz, 2013b). In one of these studies, it has been pointed out that the public libraries in Turkey have several problems related to aesthetics of space, and that the most important step toward improvement would be awareness formation on the part both of the library staff and of the decision makers they operate under (Y1lmaz, 2013b: 72).

\section{Staff}

In the delivery of public library services to the users, the library staff is one of the most crucial elements. Qualified public library staff directly contribute to the development of the library they are affiliated with. As of 2013, public libraries in Turkey had a total staff number of 3386 (see Figure 2), of which 511 (15\%) are graduates of librarianship programs (see Figure 3). The distribution of the public library staff based on educational qualifications is presented in Table 1. A close look at Table 1 reveals that university graduates of any programs constitute less than half $(44.6 \%)$ of the total.

When the total number of public library staff in the past decade is considered based on annual changes, one may observe slight fluctuations between the years, but it is clearly seen that from 2004 to 2013, the total number of public library staff increased by $15 \%$.

Likewise, it is possible to observe a relative increase in the percentage of librarianship program graduates within the total number of staff across this period. More specifically, while the librarianship graduates made up only $11 \%$ of the total number in 2004, in 2013 the figure increased to $15 \%$, which is the highest percentage so far. Despite the positive connotations of this increase, it is not possible to state that there is at least one librarianship program graduate in every single public library in Turkey. At this point, one needs to study Figure 4, in which the distribution of librarianship program graduates by province is given. As the Figure shows, there is at least one librarianship program graduate in every province of Turkey. Nonetheless, it has been found that in each of the provinces of Ağr1, Aksaray, Bitlis, Elazığ, Muş, Siirt and Şırnak, only one librarianship program graduate is employed. A relevant fact to take into consideration in evaluating this figure is that every province in Turkey has more than one public 


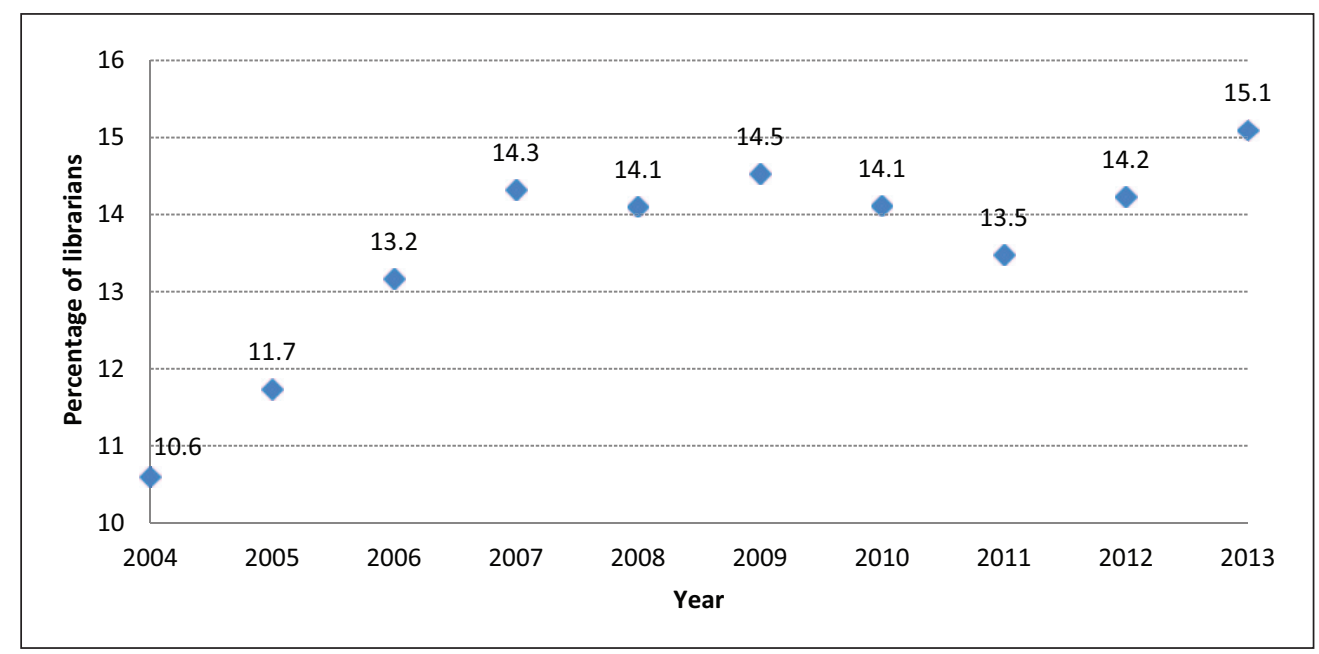

Figure 3. The percentage of librarianship program graduates within the total number of staff across the 2004-20I3 decade. Source: Kültür ve Turizm Bakanlığı (20I4).

Table I. Educational qualifications of staff.

\begin{tabular}{lrr}
\hline Educational qualification & \multicolumn{1}{c}{$\mathrm{N}$} & \multicolumn{1}{c}{$\%$} \\
\hline Graduate of librarianship program & $5 \mathrm{II}$ & 15.1 \\
University graduate excluding & 999 & 29.5 \\
librarianship program & & \\
High school graduate & $1,36 \mathrm{I}$ & 40.2 \\
Secondary school graduate & 370 & 10.9 \\
Elementary school graduate & 145 & 4.3 \\
Total & 3386 & 100.0 \\
\hline
\end{tabular}

Source: Kültür ve Turizm Bakanlığı (2014).

library (see Figure 1). For instance, in the province of Ağr1, where only one librarianship program graduate is employed, there are six public libraries; and similarly Bitlis has seven public libraries.

The increase in Figure 3 is mostly the result of recent legislation which has relatively improved the status of librarian positions in the public libraries. Another reason may be the increase of interest among the graduates of librarianship programs in being employed in public libraries, as compared to previous periods. Nevertheless, as Figure 4 clearly shows, there is major imbalance in the distribution of librarianship program graduates in provinces and in individual public libraries. It is observed that librarianship program graduates are heavily underrepresented especially in the provinces of eastern Turkey and that this inevitably has undesirable effects on the delivery of services in some public libraries.

\section{Users}

Statistical data about users of public libraries in Turkey are collected under two subheadings: the number of users and the number of registered users. In this study, the number of registered users will be taken as the point of reference for the evaluations to be offered. The main reason for the omission of the number of users is that public libraries in Turkey keep their logs based on "individual users", which results in the statistical counting of one individual user for multiple times within the same library. Moreover, in most international evaluations the number of registered-users is taken as the basis. Another reason for the preference, therefore, is to ensure congruity for the country-comparative remarks that will be presented in the following sections.

Figure 5 shows the annual increase in the total number of registered users at the public libraries in Turkey. As of the end of 2013, the total number of registered public library users in Turkey was more than one million. With respect to the total population of Turkey in the same period, it was found that as of 2013, only one person out of 100 was a registered public library user in Turkey.

With reference to the imbalance in the distribution of librarianship program graduates in the provinces as shown in Figure 4, as similar uneven distribution is observed in Figure 6 which shows the percentage of registered public library user population within the total population in each province. Accordingly, while the percentage of registered public library user population within the total population is above $5 \%$ in relatively small and less populated provinces such as Ardahan, Bayburt, Çankırı, and Iğdır; in large metropolitan provinces like Ankara, İstanbul, and İzmir, the percentage of registered public library user population within the total population is not even $1 \%$.

\section{Collections}

As of the end of 2013, the public libraries in Turkey have in their inventories more than 16 million books and approximately 80,000 volumes of periodical publications. It is observed that there was a gradual expansion of the 


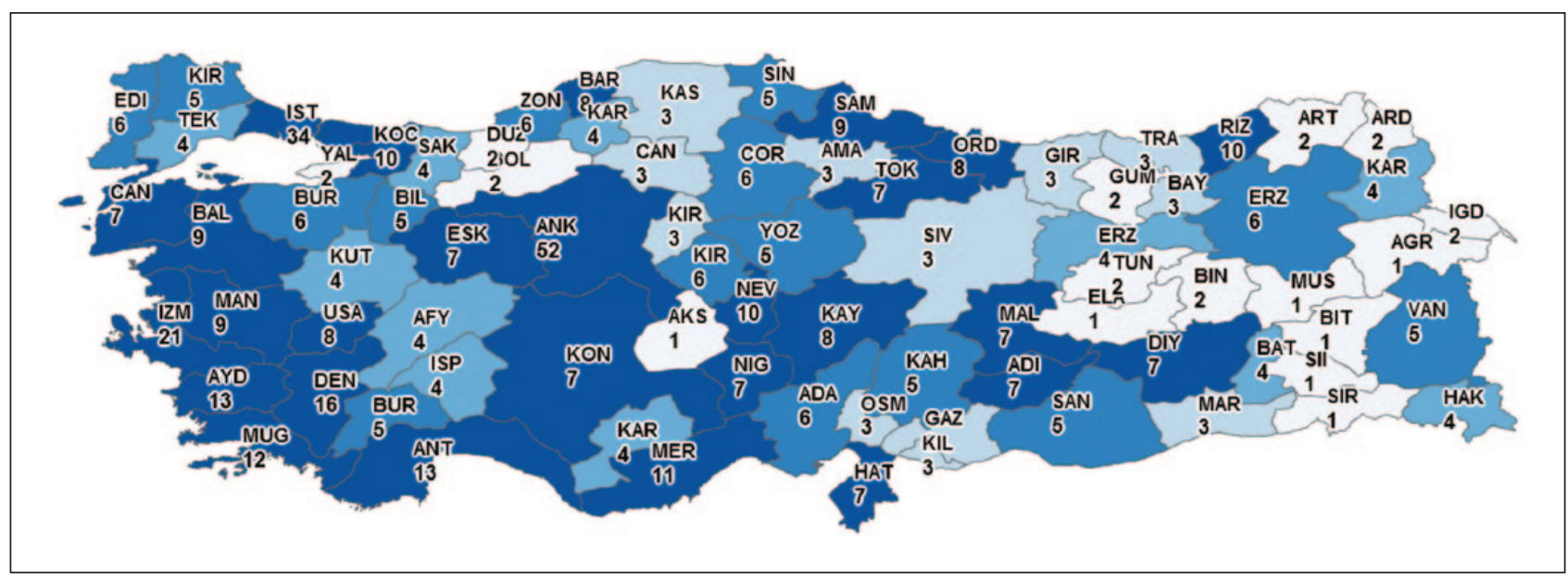

Figure 4. Distribution of librarianship program graduates in the provinces of Turkey.

Source: Kültür ve Turizm Bakanlığı (20I4).

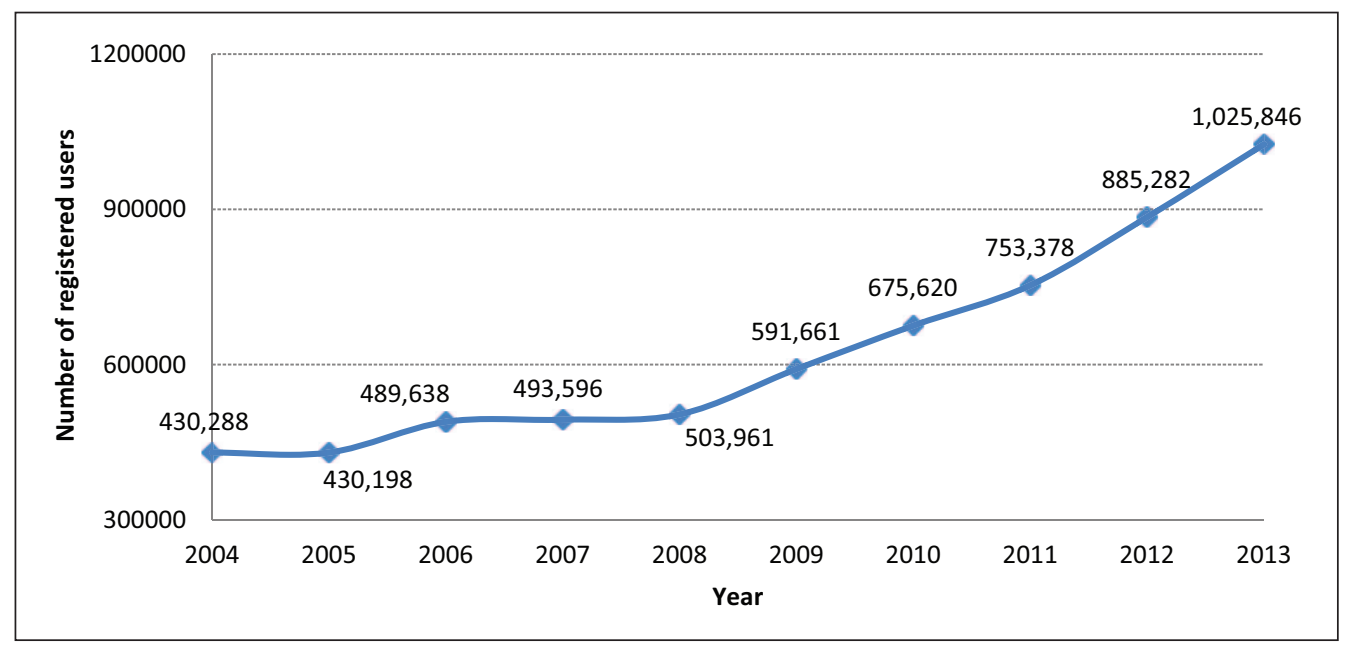

Figure 5. The annual increase in the total number of registered users at the public libraries in Turkey. Source: Kültür ve Turizm Bakanlığı (20l4).

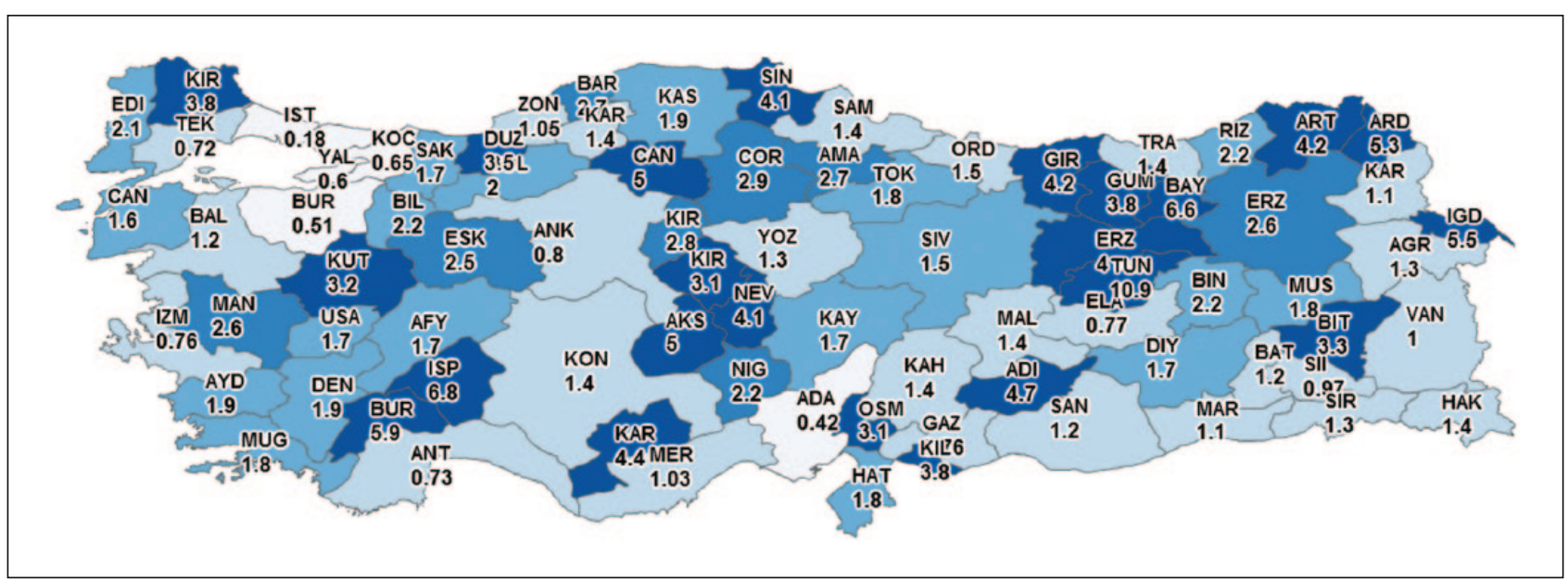

Figure 6. The percentage of registered public library user population within the total population by provinces (20I3). Source: Kültür ve Turizm Bakanlığı (20I4). 


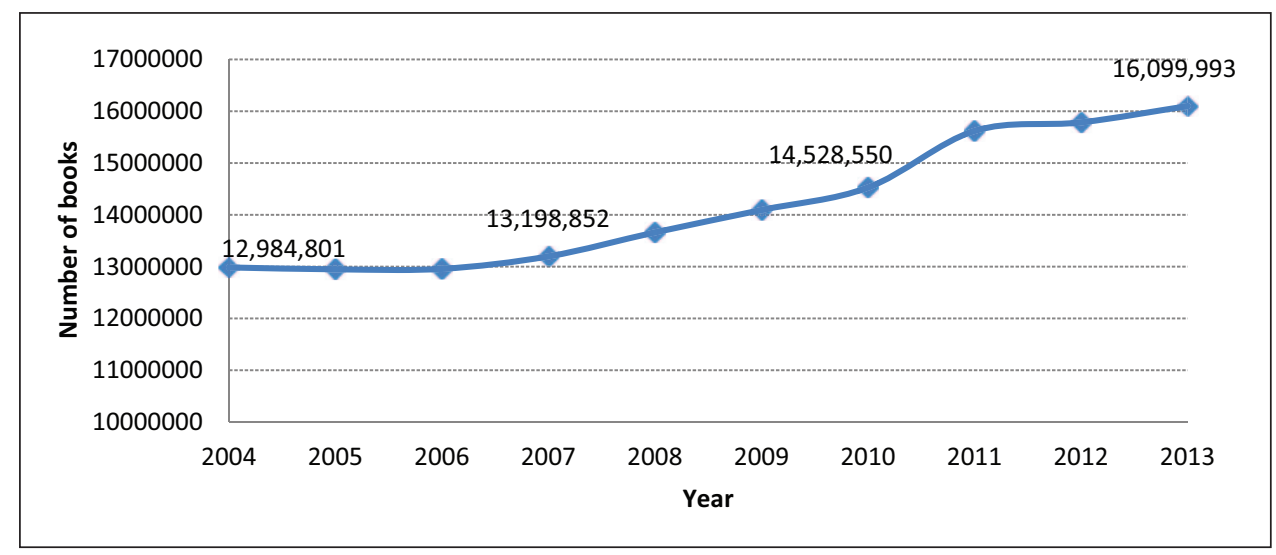

Figure 7. The total number of books in public libraries in the 2004-2013 decade. Source: Kültür ve Turizm Bakanlığı (20l4).

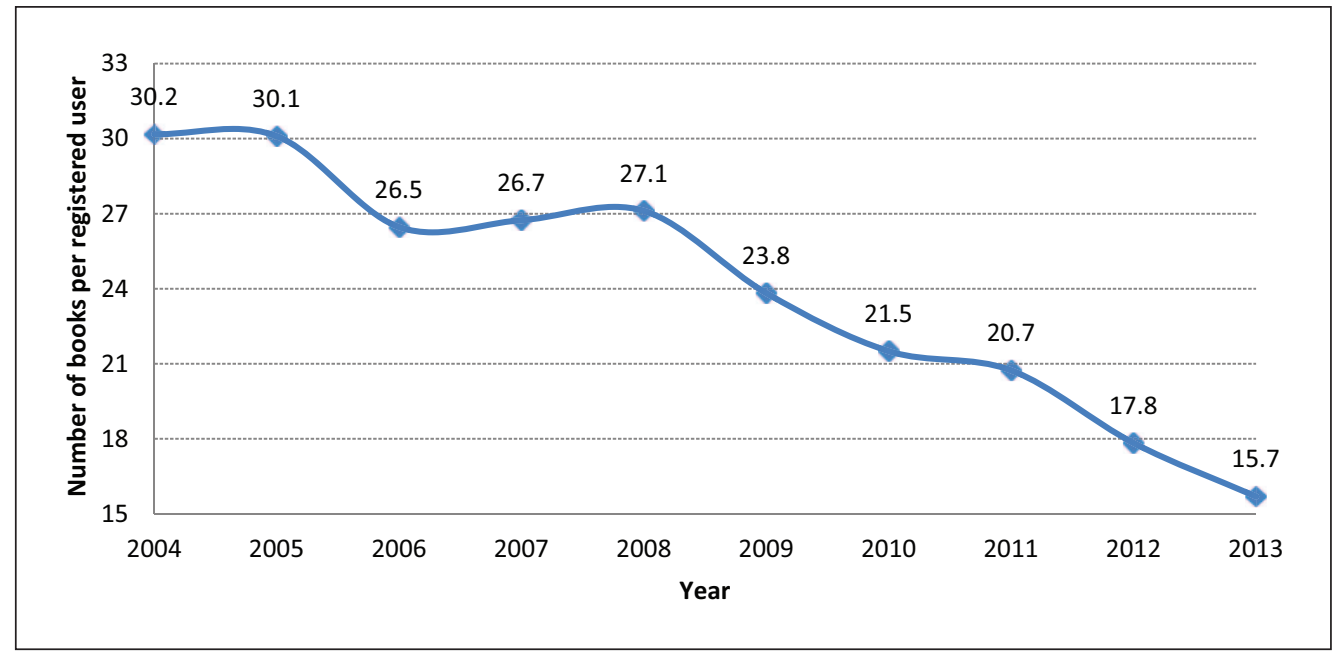

Figure 8. The total number of books per registered user in public libraries in the 2004-2013 decade. Source: Kültür ve Turizm Bakanlığı (20l4).

collections of the public libraries from 2004 to 2013. In this period, the total number of books in the public libraries in Turkey increased by $24 \%$. When Figure 7 is studied, it is observed that the greatest increase occurred after 2007.

Even though a significant increase is observed in the total number of books, when considered together with the total number of registered users, a different picture appears: The total number of books per registered user in public libraries has decreased almost by half from 2004 to 2013 (see Figure 8). This is an indication of the discrepancy resulting from the difference between the increase rates of registered users and the number of books in public library collections.

\section{Budget}

All expenditure of public libraries in Turkey is planned and funded by the GDLP. Therefore, to understand their financial structure, the structure of the central government budget also needs to be known. The Ministry of Culture and Tourism is categorized as "institutions with general budget" and therefore is subject to the annual central government budget prepared by the Ministry of Finance. The planning of the annual budget of the GDLP, therefore, is also done as part of the annual central government budget by the Ministry of Finance. Table 2 and Table 3 below have been prepared by using the figures from the documents provided by the Ministry of Culture and Tourism, and the General Directorate of Budget and Financial Control of the Ministry of Finance.

In Table 2, it is observed that the percentage of the GDLP budget within the total budget of the Ministry of Culture and Tourism has been increasing annually for the past three years. In 2013, the GDLP was allocated approximately $11 \%$ of the total budget of the Ministry. Table 3 shows the distribution of the GDLP budget among 
Table 2. 20II-20I3 budget comparison.

\begin{tabular}{lllll}
\hline Year & Central budget (TL) & $\begin{array}{l}\text { Amount allocated to } \\
\text { Ministry of Culture and } \\
\text { Tourism in the central } \\
\text { budget (TL) }\end{array}$ & $\begin{array}{l}\text { Amount allocated to the } \\
\text { GDLP in the budget of } \\
\text { the Ministry of Culture } \\
\text { and Tourism (TL) }\end{array}$ & $\begin{array}{l}\text { The percentage of the } \\
\text { GDLP budget within } \\
\text { the total budget of the } \\
\text { Ministry }\end{array}$ \\
\hline 2013 & $444,045,669,000$ & $1,851,734,000$ & $197,285,680$ & 10.65 \\
2012 & $350,898,317,871$ & $1,705,076,000$ & $161,528,000$ & 9.47 \\
2011 & $312,572,607,330$ & $1,510,066,000$ & $114,255,000$ & 7.57 \\
\hline
\end{tabular}

Sources: BUMKO (20I3); Kültür ve Turizm Bakanlığı (20I3).

Table 3. The distribution of the GDLP budget among different expenditure items in the past three years (TL).

\begin{tabular}{llll}
\hline Year & Staff costs & Physical infrastructure costs & Computer procurement costs \\
\hline 2013 & $89,934,000$ & $20,884,069$ & $2,280,000$ \\
2012 & $69,770,000$ & $13,508,390$ & $1,862,000$ \\
2011 & $57,386,000$ & $10,698,037$ & 990,000 \\
\hline
\end{tabular}

Sources: BUMKO (20।3); Kültür ve Turizm Bakanlığı (20।3).

different expenditure items. According to these figures, almost half of the budget of the GDLP is allocated for staff costs. Likewise, in the 2011-2013 period, every year there was an increase in the amounts allocated for both physical and technological infrastructure.

As the figures given in this subheading and their interpretation show, in recent years there has been a general increase in the Turkish Government's financial investment in public libraries; a welcome development. To briefly comment on the most obvious reason for this development, one may refer to the political stability of the past decade, which resulted also in economic development and general welfare of the country. Studying the data from the Turkish Statistics Institute with reference to economic indicators (gross domestic product, growth rate, etc.) of the past decade would provide enough evidence for this assumption (TÜİK, 2014). It seems that having resolved the essential and priority issues in the political and macroeconomic spheres, the central government in Turkey has been able to increasingly extend the benefits of this newlyacquired welfare to the delivery of secondary, though definitely not unimportant, services such as the improvement of public libraries.

\section{Comparisons with some European countries}

To have a better insight about the present state of the public libraries in Turkey, this study also offers quantitative comparisons with some European countries. To this end, various sources that contain numerical data about public libraries have been studied. Some of the sources were excluded from the evaluation due to lack of up-to-date data or the data from the period selected for this comparison; and some other types of data were also excluded because of the difficulty in making meaningful comparison. ${ }^{4}$ Eventually, the data from the research conducted by the European Bureau of Library, Information and Documentation Associations (EBLIDA, 2013) were used. Country population data were obtained from the World Bank (2014). For meaningful comparison, country population data from 2011 were used as this was the year when EBLIDA research was conducted (EBLIDA, 2013).

In Table 4 and Table 5, selected public library statistics from 19 countries including Turkey are presented. When compared to Turkey, most European countries have smaller populations. Among the countries represented in the tables, only Germany has a larger population than Turkey. However, for the purposes of this study, it has been assumed that the differences of population size will not lead to misconceptions in evaluating public libraries which are responsible for providing services for all segments of these societies. On the contrary, the differences of population size may be seen as facilitating some striking findings. For example, with reference to the total number of registered library users, it is seen that Spain, the population of which is about 27 million smaller than Turkey, has a total number of registered users that is 13.5 million more than the figure in Turkey. To put it differently, the total number of registered public library users in Spain is 18 times greater than the number in Turkey. It is also worth noting that in many countries with smaller populations than Turkey, the number of public libraries is far greater than the number in Turkey (see Table 4).

With reference to the statistics based on the proportion between total population and the number of public libraries, it is seen that as of 2011 there was one public library per 64,999 citizens in Turkey. The size of the population 
Table 4. Numbers of public libraries, registered users, collection size and staff by country.

\begin{tabular}{|c|c|c|c|c|c|}
\hline Country & $\begin{array}{l}\text { Total number of } \\
\text { public libraries }\end{array}$ & $\begin{array}{l}\text { Total number of } \\
\text { registered users }\end{array}$ & Total collection & Total number of staff & Population \\
\hline Austria & 1473 & 996,540 & $10,624,472$ & 914 & $8,423,635$ \\
\hline Croatia & 319 & 530,261 & 375,116 & 1650 & $4,280,600$ \\
\hline Czech Republic & 5407 & $|, 430,99|$ & $57,2 \mid 4,068$ & 4878 & $10,496,088$ \\
\hline Denmark & 641 & NA & $22,000,000$ & 4319 & $5,570,572$ \\
\hline Finland & 979 & $2,095,336$ & $39,311,127$ & 4755 & 5,388272 \\
\hline Germany & 9550 & $7,900,000$ & $124,000,000$ & 11,620 & $81,979,673$ \\
\hline Hungary & 3530 & $\mathrm{I}, 548,528$ & $44,065,386$ & 5643 & $9,971,727$ \\
\hline Latvia & 819 & 446,050 & $9,276,163$ & 2152 & $2,058,184$ \\
\hline Lithuania & 65 & 690,564 & $18,619,307$ & 3803 & $3,030,173$ \\
\hline Netherlands & $163^{*}$ & $4,009,000$ & $30,667,000$ & 8340 & $16,693,074$ \\
\hline Norway & 744 & NA & $6,265,120$ & 2492 & $4,953,088$ \\
\hline Poland & 8290 & $8,915,894$ & I 32,534,240 & 23,457 & $38,534,157$ \\
\hline Portugal & 194 & $\mathrm{I}, 163,480$ & 644,990 & 2422 & $10,556,999$ \\
\hline Serbia & 554 & 536,960 & $12,877,937$ & 1979 & $7,258,745$ \\
\hline Slovak Republic & 1916 & 485,822 & $16,534,607$ & 1462 & $5,398,384$ \\
\hline Spain & 5075 & $|3,570,8| 4$ & $8,867,886$ & $|2,82|$ & $46,|74,60|$ \\
\hline Sweden & 1212 & $2,753,208$ & $39,572,088$ & 5553 & $9,449,213$ \\
\hline Turkey & 1124 & 753,378 & $|5,62|, 478$ & 3391 & $73,058,638$ \\
\hline United Kingdom & 4698 & $|I, 4| 2,000$ & $102,305,000$ & 21,779 & $62,752,472$ \\
\hline
\end{tabular}

Sources: EBLIDA (20I3); World Bank (20|4).

*In the Netherlands there are II 77 service establishments in addition to 163 libraries.

Table 5. Overview of public libraries based on country population.

\begin{tabular}{lclcc}
\hline Country & $\begin{array}{l}\text { Population served } \\
\text { by one library }\end{array}$ & $\begin{array}{l}\text { Percentage of registered } \\
\text { users with the total } \\
\text { population }\end{array}$ & $\begin{array}{l}\text { Collection item } \\
\text { per capita }\end{array}$ & $\begin{array}{l}\text { Size of population } \\
\text { served by one } \\
\text { library staff }\end{array}$ \\
\hline Austria & 5719 & 11.8 & 1.3 & 9216 \\
Croatia & 13,419 & 12.4 & 0.1 & 2594 \\
Czech Republic & 1941 & 13.6 & 5.5 & 2152 \\
Denmark & 8690 & NA & 3.9 & 1290 \\
Finland & 5504 & 38.9 & 7.3 & 1133 \\
Germany & 8565 & 9.7 & 1.5 & 7039 \\
Hungary & 2825 & 15.5 & 4.4 & 1767 \\
Latvia & 2513 & 21.7 & 4.5 & 956 \\
Lithuania & 46,618 & 22.8 & 6.1 & 797 \\
Netherlands & 102,411 & 24.0 & 1.8 & 2002 \\
Norway & 6657 & NA & 1.3 & 1988 \\
Poland & 4648 & 23.1 & 3.4 & 1643 \\
Portugal & 54,418 & 11.0 & 0.1 & 4359 \\
Serbia & 13,102 & 7.4 & 1.8 & 3668 \\
Slovak Republic & 2818 & 9.0 & 3.1 & 3692 \\
Spain & 9098 & 29.4 & 0.2 & 3601 \\
Sweden & 7796 & 29.1 & 4.2 & 1702 \\
Turkey & 64,999 & 1.0 & 0.2 & 21,545 \\
United Kingdom & 13,357 & 18.2 & 1.6 & 2881 \\
\hline
\end{tabular}

Sources: EBLIDA (20I3); World Bank (2014).

served by one public library is 1941 in the Czech Republic, 2513 in Latvia, and 2818 in the Slovak Republic. In the 18 European countries, excluding Turkey, the total population in 2011 was $332,787,657$ and there were 45,629 public libraries. In the 18-country evaluation, one public library serves 7293 citizens. This figure is very 
important in terms of showing the need for more public libraries in Turkey.

Perhaps a more important point than the quantity of public libraries is the usage rate of public libraries. The percentage of registered users within the total populations of individual countries provides meaningful ideas and also facilitates an evaluation of the perception of public libraries by the citizens of individual countries. Accordingly, as of 2011, only one citizen out of 100 is a registered public library user in Turkey, and this is the lowest figure among the countries that are under study here. The same ratio is 39 out of 100 in Finland, and 29 out of 100 in both Spain and Sweden. The second lowest ratio is in Serbia and even there 7\% of the population are registered public library users.

Another point of reference in evaluating the present situation is the collection size at public libraries. Turkey is among the four countries where the number of collection items per capita is lowest, the other three countries being Portugal, Croatia and Spain. While each collection item corresponds to five citizens in Turkey, in Finland there are seven collection items per capita.

In evaluating the adequacy of the number of public library staff, the figure relating to the size of the population served by one library staff member becomes important. In Turkey, the total number of library staff is very low with reference to the total population size. In a context in which every citizen is considered as a potential public library user, one member of public library staff in Turkey serves a population of 21,545. When compared with other European countries, this figure is extremely high and is bound to adversely affect the delivery of public library services. When the countries listed in Table 5, excluding Turkey, are evaluated collectively, the 18-country figure for the size of population served by one library staff member is found to be 2772. In some countries (Latvia and Lithuania), the figure is below one thousand citizens.

\section{Conclusion}

Public libraries are institutions that are responsible for meeting the information needs of people from all segments of societies. Today, public libraries in Turkey are government institutions administered by the General Directorate of Libraries and Publication of the Ministry of Culture and Tourism. Various indicators suggest that there is an increasing general interest in the public libraries in Turkey. With reference to the literature in the field, and in the light of the statistical data and comparisons offered in this study, the conclusions below may be drawn as regards the public libraries in Turkey:

- Turkey does not have a Public Libraries Law. The main problem caused by the lack of such legislation is that public libraries are not able to operate under complete legal security.

- An overview of the public library-related statistics in Turkey reveals that there have been significant improvements in recent years as regards the number of books, the number of registered users and the size of budget allocations. This acceleration may be related to various recent activities such as intensive projects, regional seminars and symposia on public libraries.

- Even though efforts in the right direction have brought public libraries in Turkey to a certain level, comparisons with other countries indicate that much has yet to be done. There is a particular need for planned activities that will facilitate the diffusion of public library use across the country.

- It is inevitable that the role of the public library must be revised to adapt to changing circumstances. For the public to value and own the public libraries, they must evolve and re-structure their services to address the actual needs of the target communities they serve. To this end, paths of potential collaboration (i.e. with local governments, the information management departments of universities, and professional associations) must be explored.

\section{Funding}

First and foremost, the authors would like to acknowledge the invaluable support of the Global Libraries Initiative of the Bill \& Melinda Gates Foundation, which has generously funded the Librar-e Turkey Project and thereby has made this study possible. The authors also extend their gratefulness to the General Directorate of Libraries and Publications of the Ministry of Culture and Tourism of Turkey that has provided institutional support for this study. This acknowledgement would be remiss without an expression of gratitude to Erhan Erkan for making available a significant portion of the data used in the study and also to Müge Akbulut for her efforts in the visualization of the data.

\section{Notes}

1. The system of public libraries in Turkey is centrally governed by the General Directorate of Libraries and Publications (GDLP) of the Ministry of Culture and Tourism, and, therefore, the term "public library" in its most common use in Turkey refers to these public libraries. Accordingly, the libraries that are governed by other public and private entities such as municipalities, educational institutions or charitable foundations and are open to the "public," are not included in the scope of this study.

2. People's Houses, known as halkevleri in Turkish, were early Republican institutions (active from 1932 to 1950) which aimed at educating the general public, molding a new political culture aligned with the principles of the new regimé, and creating a platform for the members of community to interact and communicate with one another. 
3. In Turkey the names of the ministries are changed quite often due to various reasons. In the past the Ministry of Culture was a separate entity, but later it was re-organized under the names Ministry of National Education and Culture and Ministry of Culture and Tourism. The current name is Ministry of Culture and Tourism.

4. Those countries from which multiple statistical data about the number of registered users, the size of collection and the library staff could not be obtained (such as Bosnia and Herzegovina, Luxembourg, and Iceland) were excluded from the evaluation.

\section{References}

Baysal J (1992) Kitap ve kütüphane tarihine giriş [Introduction to Book and Library History]. İstanbul: Türk Kütüphaneciler Derneği.

BUMKO (2013) Bütçe ve Mali Kontrol Genel Müdürlüğü [General Directorate of Budget and Fiscal Control]. Available at: http://www.bumko.gov.tr (accessed 10 August 2014).

EBLIDA (2013) Knowledge and Information Centre (KIC) Survey. Available at: http://www.eblida.org/Activities/ KIC/EBLIDA-Knowledge-and-Information-Centre-KICSurvey-may-2013.pdf (accessed 10 August 2014).

Gardner FM (1971) Public Library Legislation: A Comparative Study. Paris: UNESCO.

Hazırlar MA (2004) Halk kütüphanelerinde iç mimari [Interior design in public libraries]. Unpublished Masters Thesis, Hacettepe University, Ankara, Turkey.

KYGM (2013) Bilgiye Erişimde Engelli Değilsiniz (BÍLED) Projesi [You are not Disabled in Accessing Information Project]. Available at: http://www.kygm.gov.tr/TR,46230/ bilgiye-erisimde-engelli-degilsiniz-biled-projesi-basin-. html (accessed 21 June 2014).

Keseroğlu HS (1989) Halk kütüphanesi politikası ve Türkiye Cumhuriyeti'nde durum [Public Library Policy and State of the Art in the Republic of Turkey]. İstanbul: Türk Kütüphaneciler Derneği.

Koşay HZ (1960) Kütüphanelere dair [About libraries]. Türk Kütüphaneciler Derneği Bülteni 9(1/2): 36-40.

Kültür ve Turizm Bakanlığg (2014) Istatistikler [Statistics] Available at: http://www.earsiv.gov.tr/stat/ (accessed 5 August 2014).

Kültür ve Turizm Bakanlığı (2013) Strateji Geliştirme Başkanlığg [Directorate of Strategy Development] Available at: http:// sgb.kulturturizm.gov.tr/ (accessed 5 August 2014).

Kütüphan-e Türkiye (2014) Genel bilgi [General information]. Available at: http://www.kutuphaneturkiye.org.tr/genelbilgi/ (accessed 5 August 2014).

MilliKütüphane(2014)Tarihçe[History]Availableat:http://www. mkutup.gov.tr/tr/Sayfalar/Hakkimizda/tarihce-kronoloji. aspx (accessed 21 June 2014).

Shera JH (1949) Foundations of the Public Library. Chicago: University of Chicago Press.

Sağlamtunç T (1995) Public libraries in Turkey. Türk Kütüphaneciliği 9(3): 245-248.

TÜIK (2014) Turkish Statistical Institute. Available at: www. tuik.gov.tr/ (accessed 22 October 2014).

Williamson M (2000) Social exclusion and the public library: A Habermasian insight. Journal of Librarianship and Information Science 32(4): 178-186.
World Bank (2014) Population. Available at: http://data. worldbank.org/indicator/SP.POP.TOTL (accessed 5 August 2014).

Yalvac M (2004) New public libraries system model and information society technology in Turkey. Library Hi Tech News 21(7): 18-24.

Y1lmaz B (1998) A sociological study of public library use in Ankara, Turkey. Journal of Librarianship and Information Science 30(4): 259-267.

Yılmaz B (2004) Türk kütüphaneciliğinde siyaset öğesi [Politics in Turkish librarianship]. In: Kütüphaneciliğin Destanı Uluslararası Sempozyumu, 21-24 Ekim 2004, Ankara, Turkey, pp. 317-329. Ankara: Ankara University.

Y1lmaz B (2005) Türkiye'de kamu yönetiminin yeniden yapılandırılması süreci ve halk kütüphaneleri [Reorganization of public administration in Turkey and public libraries]. Türk Kütüphaneciliği 19(1): 56-77.

Y1lmaz B (2008) Public libraries in Turkey. Bibliothek Forschung und Praxis 32(2): 214-217.

Yilmaz B (2010) Public libraries in Turkey. Fontees Artis Musicae 57(3): 303-308.

Yılmaz B (2013a) Halk kütüphaneleri bölge seminerleri 2006-2012: Türkiye'de bir hizmetiçi eğitim modelinin değerlendirilmesi [Public libraries regional seminars 20062012: An evaluation of in-service training model in Turkey]. Türk Kütüphaneciliği 21(1): 180-185.

Y1lmaz B (2013b) Halk kütüphanelerinde mekânsal estetik [Spatial aesthetics in public libraries]. In: 3. Halk Kütüphaneciliği Sempozyumu, 8-10 Mayıs 2013, Bodrum, Turkey, pp. 69-73. Ankara: Kültür ve Turizm Bakanlığı.

\section{Author biographies}

Umut $\mathrm{Al}$ received his $\mathrm{PhD}$ in Information Management from Hacettepe University (2008). His research interests include information retrieval on the Internet, marketing of information services, university libraries, and bibliometrics. He has published numerous papers in professional journals (such as Scientometrics, Journal of the American Society for Information Science \& Technology, Library \& Information Science Research, Libri) and he is a member of professional associations (such as Turkish Librarians' Association, Association of University and Research Librarians). $\mathrm{He}$ also worked as a project manager and researcher in several national projects and as a researcher on European Union projects.

Sinan Akıllı is an Assistant Professor of English and Cultural Studies at the Department of English Language and Literature, Hacettepe University, Turkey, where he received his MA and $\mathrm{PhD}$ degrees in British Cultural Studies in 2001 and 2005, respectively. From 2005 to 2009 he lived in State College, PA, where, in addition to academic research and publication, he did voluntary work for the Global Connections Office of the Penn State University. From 2009 to 2011, he worked at the newly-founded Aksaray University in Turkey as the founding chair of Department of Western Languages and Literatures, Department of Foreign Languages, School of Foreign Languages. Sinan's current academic research and publications focus on early modern English popular culture and literature, 19th-century travel literature, adaptation studies, digital cultures, and public libraries. He teaches courses on cultural theory, and popular culture and adaptation studies, as well as supervising graduate theses. 